\title{
PENGARUH PUPUK MAJEMUK TABLET TERHADAP PERTUMBUHAN LILIT BATANG DAN HARA DAUN TANAMAN KARET
}

\section{THE EFFECT OF TABLET FERTILIZER APPLICATION ON THE GROWTH AND NUTRIENT LEAF STATUS OF RUBBER TREES}

\author{
Priyo Adi Nugroho*, Yan Riska Venata Sembiring \\ Pusat Penelitian Karet Sungei Putih, PO BOX 1415, Medan 20001 \\ *Corresponding author: priyo.nugroho@puslitkaret.co.id
}

Naskah Diterima: 02 Oktober 2019; Direvisi: 29 Maret 2020; Disetujui: 08 April 2020

\begin{abstract}
Abstrak
Harga karet alam dunia yang volatil saat ini telah menyebabkan munculnya inovasi dalam pemupukan tanaman karet diantaranya penggunaan pupuk majemuk tablet. Percobaan pemupukan telah dilakukan pada TBM karet umur 3 tahun yang bertujuan untuk mengetahui pengaruh pupuk majemuk tablet terhadap pertumbuhan lilit batang dan kandungan hara daun. Terdapat tiga perlakuan dalam penelitian ini yaitu, (A) pupuk majemuk briket $(500 \mathrm{~g} /$ pohon/tahun) sebagai kontrol, (B) pupuk majemuk tablet (200 g/pohon/tahun) atau setara dengan 40\% kontrol, dan (C) pupuk majemuk tablet (300 g/pohon/tahun) atau setara dengan 60\% kontrol. Formulasi pupuk majemuk yang digunakan adalah 18-1014-2+1TE. Hasil penelitian menunjukkan bahwa penyerapan hara $\mathrm{N}$ dan $\mathrm{K}$ pada perlakuan $\mathrm{A}$ lebih cepat yang direfleksikan melalui hara daun $\mathrm{A}$ yang lebih tinggi dibandingkan $\mathrm{B}$ dan $\mathrm{C}$. Walaupun hara daun $\mathrm{N}$ dan $\mathrm{K}$ pada perlakuan $\mathrm{A}$ relatif lebih tinggi, tetapi penambahan lilit batang terbesar terdapat pada perlakuan $\mathrm{C}$ kemudian $\mathrm{A}$ dan $\mathrm{B}$, yaitu 7,52 cm; 7,23 cm; dan $6,99 \mathrm{~cm}(\mathrm{P}=0,23)$. Tidak ditemukan korelasi yang kuat antara penambahan ukuran lilit batang dengan kandungan hara daun $(\mathrm{P}=0,66)$ tetapi terdapat korelasi positif yang cukup kuat $(\mathrm{r}=0,64 ; \mathrm{P}=0,025)$ antara penambahan ukuran lilit batang dengan curah hujan.
\end{abstract}

Kata kunci: Briket; Hevea brasiliensis; Pupuk majemuk; Slow release; Tablet

Abstract

The world's natural rubber price that is volatile has led to the innovation in rubber trees fertilization by using tablet fertilizer. The study of fertilization was conducted in an immature rubber tree three years planted (TBM 3) to find out the responses of fertilization in rubber girth and leaf nutrient content. Three treatments were established viz. (A) briquette fertilizer $500 \mathrm{~g} /$ tree/year as control, (B) tablet fertilizer 200 $\mathrm{g} /$ tree/year equivalent to $40 \%$ of control, $(C)$ tablet fertilizer $300 \mathrm{~g} /$ tree/year equivalent to $60 \%$ of control. The formula of briquette and tablet was identic (18-10-14-2+1TE). The results showed that nitrogen and potassium uptake in treatment of briquette fertilizer $500 \mathrm{~g} /$ tree/year $(A)$ was faster than $B$ and $C$, that was reflected through leaf nutrient content. Even though the contents of $N$ and $K$ in rubber leaf in $A$ was relatively higher, the highest girth increment occurred in $C$ then $A$ and $B$, i.e. $7.52 \mathrm{~cm} ; 7.23 \mathrm{~cm}$; and 6.99 $\mathrm{cm}$, respectively. No strong correlation between girth size increment and nutrient leaf status in this study $(P$ $=0.66)$. However a moderately strong correlation $(r=0.64 ; P=0.025)$ appeared between girth size increment and monthly precipitation.

Keywords: Briquettes; Compound fertilizer; Hevea brasiliensis; Slow release; Tablet

Permalink/DOI: http://dx.doi.org/10.15408/kauniyah.v13i1.12768 


\section{PENDAHULUAN}

Dalam pengelolaan tanaman karet yang belum menghasilkan (TBM), pemupukan merupakan salah satu faktor penting dan utama yang mutlak dilakukan untuk memperoleh TBM karet yang prima. Pada kondisi harga karet alam yang masih sangat volatil, pemupukan yang paling efektif dan efisien adalah hal yang harus benar-benar diperhatikan agar respon pupuk yang diberikan pada tanaman sesuai dengan yang diharapkan. Menurut Nugroho dan Istianto (2010), terdapat beberapa cara untuk meningkatkan efektivitas dan efisiensi pemupukan, salah satunya adalah penggunaan bahan aditif. Sudah sejak lama bahan aditif seperti batuan fosfat alam (Idris, 1995; Nasution, 2002), zeolite (Agustin, Abdoellah, \& Bowo, 2010) dan polymer latex (Arizal, 2001; Lan et al., 2011) diformulasikan sebagai carrier dalam pembuatan pupuk majemuk.

Bahan aditif Bersama ditambahbahanbahan pupuk seperti nitrogen, fosfor, kalium, dan magnesium selanjutnya diformulasi ke dalam suatu jenis pupuk yang mengandung jenis hara yang cukup lengkap dan dapat dikendalikan pelepasannya (slow release). Menurut Trenkel (2010), mekanisme penyediaan hara oleh pupuk lepas lambat (slow release) ke tanaman lebih lambat dan lebih sedikit, tetapi jangka waktu pelepasan hara lebih panjang. Dalam dua dasawarsa terakhir penggunaan pupuk majemuk di perkebunan karet di Indonesia sudah cukup masif. Hal ini karena sulitnya memperoleh pupuk tunggal secara serentak dengan jumlah yang besar dan upah tenaga kerja yang terus meningkat dari tahun ke tahun (Premono, 2006).

Briket dan tablet adalah jenis-jenis pupuk majemuk slow release yang sudah cukup populer digunakan di perkebunan karet. Kedua jenis pupuk ini memiliki keunggulan diantaranya mengurangi kehilangan hara, meningkatkan ketersediaan hara, mengurangi stress tanaman akibat penggunaan pupuk berlebih, mengurangi resiko pencemaran lingkungan, dan dapat menekan biaya aplikasi (Shaviv, 2000; Saputra, Ardika, \& Wijaya, 2017; Supriyadi, Diana, \& Djumali, 2017). Pengujian efektivitas pupuk briket dan tablet dibandingkan dengan pupuk tunggal pada tanaman karet telah dilakukan oleh Pusat Penelitian Karet. Pemberian 2 tablet pupuk dengan berat sekitar 12,36 g, komposisi hara 20-15-10-1+TE pada tanaman karet belum menghasilkan umur 1,5 tahun klon PB 260, menunjukkan hasil pertumbuhan lilit batang yang tidak berbeda nyata dibandingkan dengan tanaman yang dipupuk menggunakan pupuk tunggal urea, TSP, $\mathrm{KCl}$, dan Kieserit (Nasution, 1994). Istianto (2006) juga melaporkan bahwa pemupukan dengan pupuk majemuk briket formulasi 18-10-14-2+TE di areal TBM pada beberapa kebun karet di Sumatera Utara selama 12 bulan menunjukkan hasil yang tidak berbeda nyata dengan pertumbuhan lilit batang TBM karet yang dipupuk menggunakan urea, $\mathrm{TSP}, \mathrm{KCl}$, dan Kieserit.

Selain keunggulannya terhadap pupuk tunggal, pupuk briket, dan tablet juga memiliki kelemahan. Biaya produksi pupuk di pabrik tergolong cukup tinggi, sehingga berpengaruh terhadap harga penjualan (Trenkel, 2010). Jika harga keduanya dibandingkan, pupuk briket relatif lebih murah dibandingkan dengan tablet. Namun belum diketahui secara pasti bagaimana pengaruh pemberian pupuk majemuk tablet dibandingkan dengan pupuk majemuk briket terhadap pertumbuhan tanaman karet belum menghasilkan (TBM). Oleh sebab itu topik tersebut sangat menarik untuk dikaji.

Penelitian ini bertujuan untuk mengetahui pengaruh pemberian pupuk majemuk tablet terhadap pertumbuhan lilit batang dan kandungan hara daun tanaman karet belum menghasilkan umur 3 tahun (TBM 3) dibandingkan dengan pupuk majemuk briket yang selama ini sering digunakan. Diharapkan hasil penelitian ini dapat dijadikan pertimbangan bagi praktisi perkebunan untuk memperoleh pemupukan yang lebih efektif dan efisien.

\section{MATERIAL DAN METODE Deskripsi Lokasi Penelitian}

Penelitian dilaksanakan di areal perkebunan karet yang terletak di Deli Serdang, Sumatera Utara. Tanaman karet yang digunakan dalam penelitian ini adalah klon PB 260 umur 3 tahun (TBM 3). Pada tahun pertama dan kedua tanaman karet dipupuk 
dengan pupuk majemuk briket 18-10-142+1TE masing-masing dengan dosis 400 dan $450 \mathrm{~g} /$ pohon/tahun sesuai rekomendasi Pusat Penelitian Karet. Areal percobaan terletak pada ketinggian $\pm 50 \mathrm{mdpl}$, jenis tanahnya adalah ultisol (soil taxonomy, USDA) dengan solum yang cukup dalam $(>2 \mathrm{~m})$. Karakteristik tanah mengacu kepada hasil survei (Syahputra,
Fauzi, \& Razali, 2015) yang dilakukan di zona ekologi karet yang sama (Nugroho \& Wijaya, 2017) dengan lokasi penelitian. Data sifat tanah disajikan pada Tabel 1. Klasifikasi iklim di lokasi penelitian tergolong ke dalam tipe basah (Schmidt Fergusson) dengan rata-rata curah hujan adalah $2.040 \mathrm{~mm} /$ tahun dan 102 hari hujan/tahun (Gambar 1).

Tabel 1. Karakteristik ultisol yang terletak pada zona ekologi yang sama dengan lokasi penelitian

\begin{tabular}{cccc}
\hline No & Karakteristik & Nilai & Harkat \\
\hline 1. & Tekstur & Clayey & - \\
& Sand $(\%)$ & 38,01 & - \\
& Silt $(\%)$ & 10,33 & - \\
& Clay $(\%)$ & 51,66 & - \\
2. & pH tanah & 4,8 & Masam \\
3. & Kapasitas Tukar Kation $(\mathrm{me} / 100 \mathrm{~g})$ & 11,24 & Rendah \\
4. & Kejenuhan basa $(\%)$ & 29,87 & Rendah \\
5. & Kejenuhan Aluminium $(\%)$ & 14,23 & Sedang \\
\hline
\end{tabular}

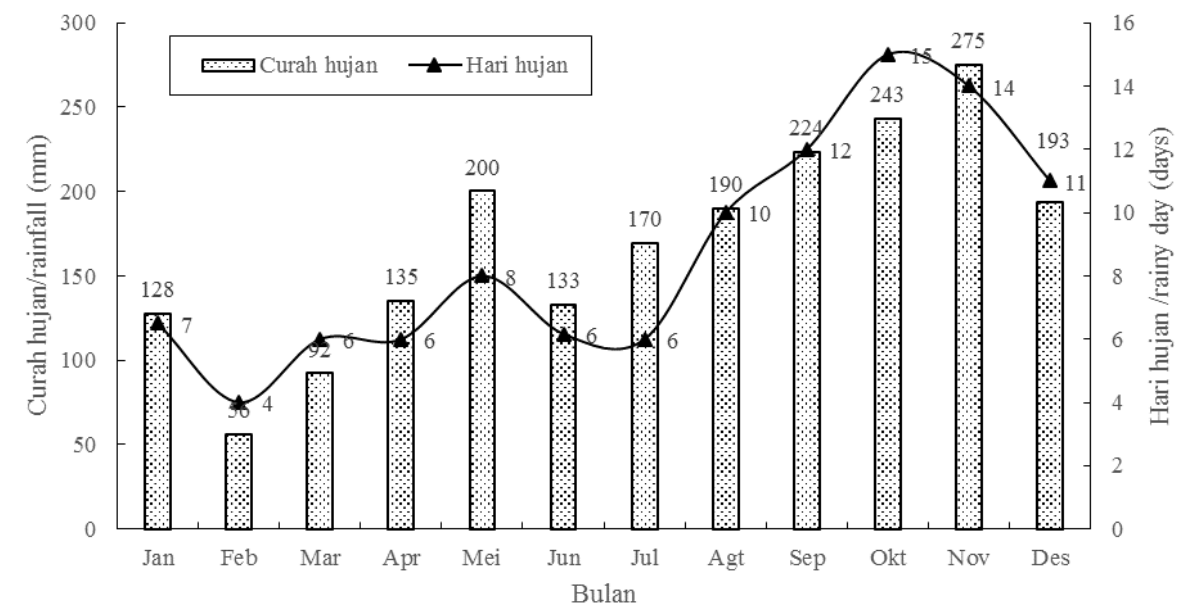

Gambar 1. Curah hujan dan hari hujan di lokasi penelitian

\section{Pelaksanaan Percobaan}

Percobaan dilaksanakan selama 12 bulan menggunakan Rancangan Acak Kelompok (RAK) dengan perlakuan berupa dosis aplikasi pupuk majemuk tablet dengan pupuk briket sebagai kontrol. Formulasi pupuk briket dan tablet yang digunakan adalah 18-10-142+1TE. Terdapat tiga perlakuan dalam penelitian ini yaitu: (A) pupuk majemuk briket (500 g/pohon/tahun) sebagai kontrol; (B) pupuk majemuk tablet (200 g/pohon/tahun) atau setara dengan 40\% kontrol; (C) pupuk majemuk tablet (300 g/pohon/tahun) atau setara dengan $60 \%$ kontrol.

Setiap perlakuan menggunakan \pm 184 pohon dengan 3 ulangan sehingga total TBM karet yang diperlukan untuk setiap perlakuan berjumlah \pm 552 pohon. Dalam penelitian ini terdapat 3 perlakuan, sehingga jumlah pohon yang akan diaplikasikan pupuk berjumlah \pm 1.656 pohon atau setara dengan luas lahan $\pm 3-4$ ha.

Aplikasi pupuk majemuk tablet diberikan dua kali per tahun. Aplikasi I dilakukan pada awal pengujian yaitu pada bulan Desember dan aplikasi II dilakukan pada bulan Juni. Sedangkan pupuk majemuk briket (perlakuan A) diaplikasikan tiga kali per tahun yaitu pada bulan April, Agustus, dan Desember atau sesuai dengan instruksi kerja di perkebunan karet yang menjadi lokasi penelitian.

\section{Parameter Pengamatan}

Terdapat dua parameter pengamatan dalam penelitian ini yaitu, (1) kandungan hara daun dan (2) pertumbuhan lilit batang TBM 
karet. Pengambilan contoh daun dilakukan pada akhir penelitian. Plot penelitian merupakan satu hamparan dengan umur tanaman dan perlakuan kultur teknis yang sama sehingga diasumsikan memiliki kondisi awal yang sama termasuk kandungan hara daunnya. Pohon contoh ditentukan dengan metode petak pewakil (40-50 pohon) di tengah plot perlakuan. Pengambilan dan preparasi sampel daun mengacu pada prosedur Pusat Penelitian Karet (Balai Penelitian Sungei Putih, 2004).

Analisis daun dilaksanakan di Laboratorium Tanah dan Daun, Balai Penelitian Sungei Putih dan Balai Penelitian Getas. Kandungan nitrogen diukur dengan metode Kjedhal, sedangkan kandungan $\mathrm{P}, \mathrm{K}$, dan $\mathrm{Mg}$ dianalisis dengan metode destruksi kering (pengabuan) menggunakan $5 \mathrm{~g}$ sampel daun, hasil pengabuan selanjutnya diekstraksi untuk diketahui kandungan haranya (Food and Agriculture Organization, 1980). Kandungan fosfor $(\mathrm{P})$ diukur dengan metode kolorimetri menggunakan Spectrophotometer (Thermo Scientific tipe Genesis 10S Vis), kandungan K diukur menggunakan Flame Photometer (Corning tipe 400) sedangkan kandungan $\mathrm{Mg}$ dan $\mathrm{Ca}$ menggunakan Atomic Absorption Spectrophotometer (Varian tipe AA240FS).

Pengamatan pertumbuhan lilit batang dilakukan setiap bulan dengan mengukur lilit batang pada ketinggian $100 \mathrm{~cm}$ dari permukaan tanah. Analisis data kandungan hara daun, pertumbuhan lilit batang dan curah hujan menggunakan bantuan software statistika SPSS 16.0 (SPSS Inc., Chicago, USA).

\section{HASIL}

\section{Kandungan Hara Daun}

Hara daun merupakan refleksi dari kemampuan tanah untuk menyediakan unsur hara yang dapat diserap oleh tanaman. Dalam penelitian ini tidak dilakukan analisis tanah, karena keterbatasan sumber daya, karakteristik tanah di lokasi penelitian diasumsikan menyerupai karakteristik tanah yang tergolong ke dalam zona ekologi yang sama (Tabel 1). Kandungan hara daun tanaman karet di areal penelitian disajikan pada Tabel 2 .

Tabel 2. Kandungan hara daun tanaman karet tiap perlakuan pemupukan

\begin{tabular}{ccccc}
\hline \multirow{2}{*}{ Perlakuan } & $\mathrm{N}$ & $\mathrm{P}$ & $\mathrm{K}$ & $\mathrm{Mg}$ \\
\cline { 2 - 5 } & \multicolumn{4}{c}{$\%$} \\
\hline $\begin{array}{c}\text { Pupuk majemuk briket } \\
\text { (500 g/pohon/tahun) (A) } \\
\begin{array}{c}\text { Pupuk majemuk tablet } \\
\text { (200 g/pohon/tahun) (B) }\end{array}\end{array}$ & $3,28 \mathrm{~b}$ & $0,17 \mathrm{a}$ & $0,77 \mathrm{~b}$ & $0,16 \mathrm{a}$ \\
$\begin{array}{c}\text { Pupuk majemuk tablet } \\
\text { (300 g/pohon/tahun) (C) }\end{array}$ & $3,09 \mathrm{a}$ & $0,17 \mathrm{a}$ & $0,61 \mathrm{a}$ & $0,16 \mathrm{a}$ \\
\hline
\end{tabular}

Keterangan: Angka yang diikuti oleh huruf yang sama, pada kolom yang sama menunjukkan tidak berbeda nyata pada taraf uji $\mathrm{P}=0,05$

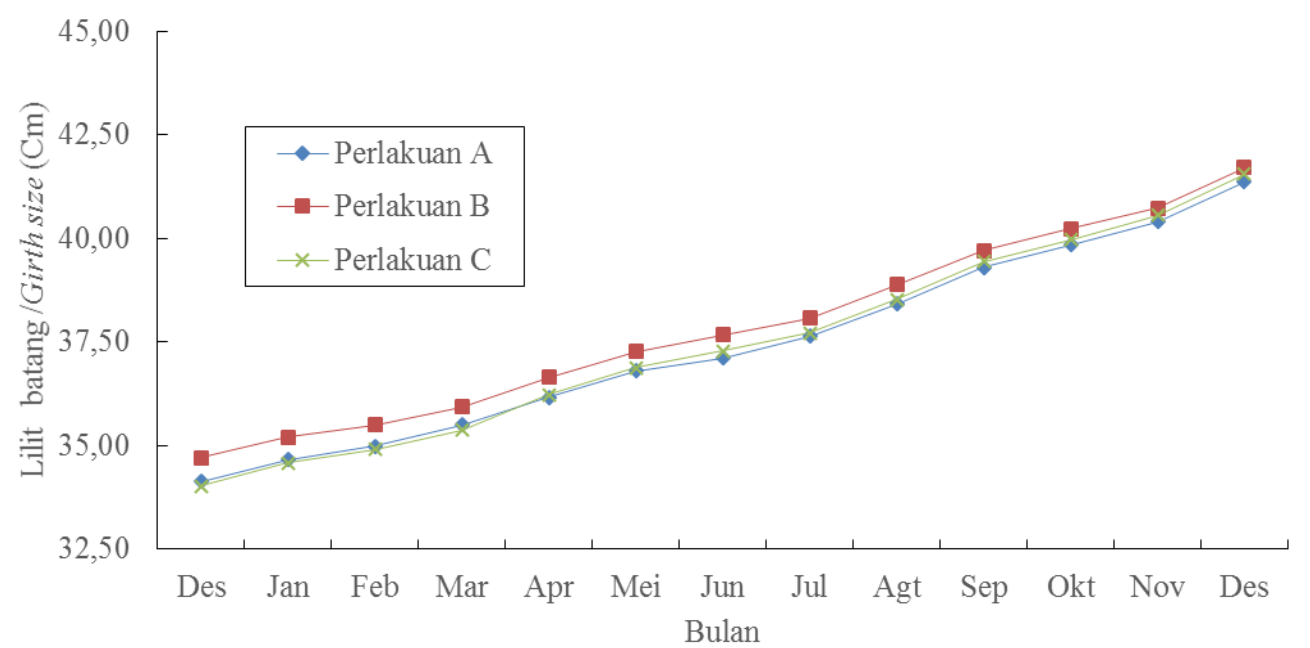

Gambar 2. Ukuran lilit batang selama penelitian 


\section{Pertumbuhan Lilit Batang Tanaman Karet}

Pertumbuhan lilit batang menunjukkan pola pertumbuhan bulanan yang relatif sama (Gambar 1), hal ini menunjukkan bahwa ketiga perlakuan pemupukan secara umum tidak menyebabkan gangguan pertumbuhan tanaman (normal). Pola pertumbuhan tanaman ketiga perlakuan pemupukan disajikan pada Gambar 1 .

Walaupun pola pertumbuhan tanaman di ketiga perlakuan menunjukkan pola yang sama (Gambar 2), namun pertambahan lilit batang selama satu tahun penelitian (Januari ke Desember) menunjukkan adanya perbedaan antar perlakuan tetapi tidak signifikan $(\mathrm{P}=$ 0,23). Pertambahan ukuran lilit batang tertinggi terdapat pada perlakuan $\mathrm{C}$ kemudian A dan B, berturut-turut sebesar 7,52 cm, 7,23 $\mathrm{cm}$ dan $6,99 \mathrm{~cm}$. Data pertambahan lilit batang per bulan ditampilkan pada Tabel 3.

Produktivitas tanaman pada masa menghasilkan (TM) bukan hanya ditentukan oleh potensi genetik dan mutu bahan tanam, tetapi juga oleh tingkat pertumbuhan dan keseragaman tanaman selama masa TBM. Tingkat keseragaman lilit batang tanaman karet selama penelitian disajikan pada Tabel 4.

Tabel 3. Pertambahan lilit batang setiap bulan di tiap perlakuan pemupukan

\begin{tabular}{|c|c|c|c|c|c|c|c|c|c|c|c|c|}
\hline \multirow{2}{*}{ Perlakuan } & \multicolumn{12}{|c|}{2014} \\
\hline & Jan & Feb & Mar & Apr & Mei & Jun & Jul & Agt & Sep & Okt & Nov & Des \\
\hline $\begin{array}{l}\text { Pupuk majemuk } \\
\text { briket } 500 \\
\text { g/pohon/tahun } \\
\text { (A) }\end{array}$ & 0,53 & 0,33 & 0,50 & 0,67 & 0,64 & 0,31 & 0,53 & 0,77 & 0,89 & 0,54 & 0,55 & 0,97 \\
\hline $\begin{array}{l}\text { Pupuk majemuk } \\
\text { tablet } 200 \\
\text { g/pohon/tahun } \\
\text { (B) }\end{array}$ & 0,49 & 0,31 & 0,43 & 0,72 & 0,62 & 0,40 & 0,40 & 0,81 & 0,83 & 0,54 & 0,49 & 0,98 \\
\hline $\begin{array}{l}\text { Pupuk majemuk } \\
\text { tablet } 300 \\
\text { g/pohon/tahun } \\
\text { (C) }\end{array}$ & 0,56 & 0,32 & 0,46 & 0,86 & 0,65 & 0,40 & 0,44 & 0,80 & 0,93 & 0,53 & 0,59 & 0,99 \\
\hline
\end{tabular}

Tabel 4. Tingkat keseragaman lilit batang tanaman selama penelitian

\begin{tabular}{ccccccc}
\hline \multirow{2}{*}{ Parameter } & \multicolumn{2}{c}{ Perlakuan A } & \multicolumn{2}{c}{ Perlakuan B } & \multicolumn{2}{c}{ Perlakuan C } \\
\cline { 2 - 7 } & Awal & Akhir & Awal & Akhir & Awal & Akhir \\
\hline Minimum $(\mathrm{cm})$ & 20,00 & 21,50 & 20,00 & 23,10 & 10,50 & 14,70 \\
Maximum $(\mathrm{cm})$ & 48,00 & 57,40 & 47,00 & 58,50 & 46,00 & 56,90 \\
Standard deviation & 4,73 & 6,21 & 4,85 & 6,43 & 4,94 & 6,53 \\
Mean $(\mathrm{cm})$ & 34,13 & 41,36 & 34,46 & 41,78 & 34,03 & 41,55 \\
Coefficient variation (\%) & 13,87 & 15,02 & 14,07 & 15,40 & 14,51 & 15,71 \\
\hline
\end{tabular}
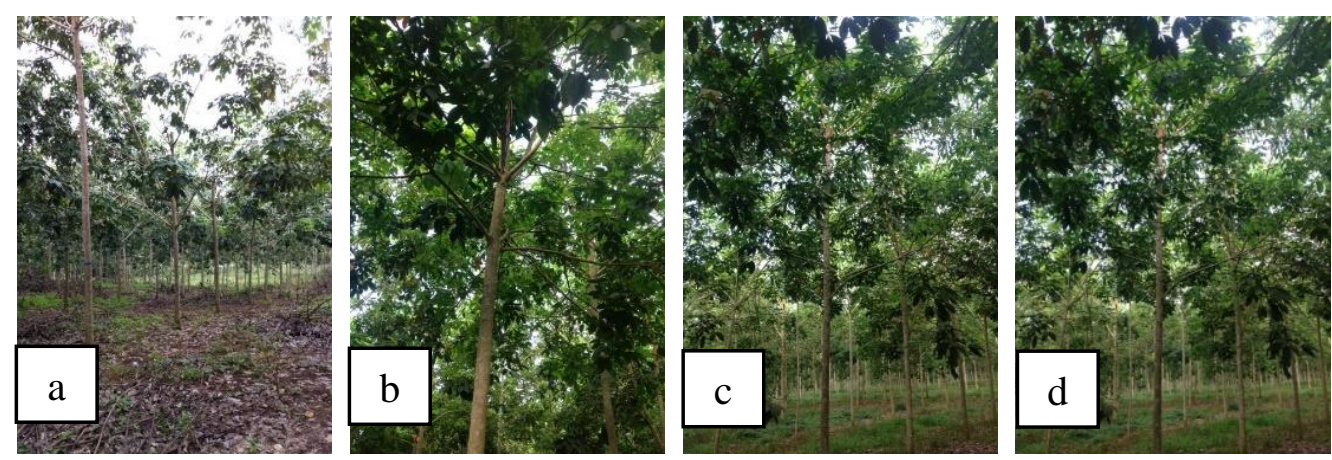

Gambar 3. (a) tajuk tanaman sebelum pemupukan, (b) setelah 6 bulan pemupukan briket 500 g/pohon/tahun, (c) setelah 6 bulan pemupukan tablet $200 \mathrm{~g} /$ pohon/tahun, (d) setelah 6 bulan pemupukan tablet $300 \mathrm{~g} /$ pohon/tahun 
Dalam penelitian ini juga diamati kondisi tajuk atau perdaunan secara visual di ketiga perlakuan. Pada 6 bulan pertama penelitian, kondisi tajuk tanaman relatif sama pada tiga perlakuan. Perdaunan terlihat baik dan sudah mulai menutupi gawangan, sehingga jumlah intersepsi cahaya matahari yang sampai ke permukaan tanah semakin berkurang (Gambar $3)$.

\section{PEMBAHASAN \\ Kandungan Hara Daun}

Hara nitrogen daun dari ketiga perlakuan dosis pemupukan berada pada kisaran cukup rendah hingga normal sedangkan hara $\mathrm{P}, \mathrm{K}$, dan $\mathrm{Mg}$ semuanya berada pada kisaran yang rendah-sangat rendah. Tidak terdapat perbedaan yang signifikan pada kandungan hara $\mathrm{P}$ dan $\mathrm{Mg}$ di setiap perlakuan pemupukan. Namun hara nitrogen dan kalium daun pada perlakuan pupuk majemuk briket (A) menunjukkan kandungan hara yang signifikan lebih tinggi $(3,28 \%$ dan $0,77 \%)$ dibandingkan dengan kedua perlakuan lainnya (B dan C). Luas permukaan reaksi adalah salah satu faktor yang memengaruhi kelarutan pupuk di dalam tanah. Pupuk briket memiliki ukuran berat sekitar 1,2 g/briket yang relatif lebih kecil dari pupuk tablet sekitar $100 \mathrm{~g} /$ tablet sehingga luas permukaan atau bidang sentuhnya dengan tanah lebih besar dibanding pupuk tablet. Semakin besar luas permukaan reaksi, kelarutan pupuk akan menjadi lebih cepat dan hara menjadi lebih cepat tersedia. Selain itu dosis pupuk yang lebih tinggi dan frekuensi pemberian pupuk majemuk briket yang lebih sering ( $3 \mathrm{x}$ setahun) daripada pupuk majemuk tablet ( $2 \mathrm{x}$ setahun) juga turut berkontribusi terhadap ketersediaan unsur hara bagi tanaman.

Beberapa penelitian terdahulu menunjukkan adanya keterkaitan antara kandungan hara daun tanaman karet dengan kandungan hara tanah (Hua, Lin, Luo, Cha, \& Chen, 2015; Nugroho \& Wijaya, 2017). Namun hal tersebut tidak terlihat nyata dalam penelitian ini. Walaupun pemupukan fosfor dan magnesium di tiap perlakuan sudah mengikuti dosis anjuran, namun belum terekfleksikan pada kandungan hara daun karet. Jenis tanah di areal penelitian adalah ultisol yang umumnya memiliki permasalahan ketersediaan P. Kejenuhan aluminium yang cukup tinggi sebesar 14,23\% (Tabel 1) pada tanah ultisol menyebabkan fosfor di dalam tanah akan membentuk ikatan Al-P sehingga $\mathrm{P}$ menjadi tidak tersedia bagi tanaman (Tan, 1991). Ultisol juga memiliki jumlah kationkation dapat ditukar (seperti $\mathrm{Mg}, \mathrm{Ca}, \mathrm{K}$, dan $\mathrm{Na}$ ) dan kapasitas tukar kation (CEC) yang rendah, serta peka terhadap erosi (Adiningsih \& Mulyadi, 1993; (Prasetyo \& Suriadikarta, 2006). Ciri tersebut sangat sesuai dengan sifat tanah (kapasitas tukar kation dan kejenuhan basa) (Tabel 1), sehingga sangatlah wajar apabila kandungan $\mathrm{K}$ dan $\mathrm{Mg}$ pada daun karet di ketiga perlakuan juga rendah.

\section{Pertumbuhan dan Keseragaman Lilit Batang}

Pola penambahan ukuran lilit batang di setiap bulan mengikuti pola curah hujan bulanan (Gambar 2) atau sangat tergantung dengan ketersediaan air tanah. Dalam penelitian ini tidak ditemukan korelasi yang kuat antara penambahan ukuran lilit batang dengan kandungan hara daun $(\mathrm{P}=0,66)$ tetapi terdapat korelasi positif yang cukup kuat $(\mathrm{r}=$ 0,64; $\mathrm{P}=0,025$ ) antara curah hujan bulanan dan penambahan lilit batang. Penambahan lilit batang tertinggi terjadi pada bulan Desember yaitu $(0,98-0,99 \mathrm{~cm})$, sedangkan penambahan lilit batang terendah terjadi pada bulan Februari dan Maret $(0,32$ dan $0,37 \mathrm{~cm})$ pada saat curah hujan bulanan $<60 \mathrm{~mm}$. Hujan merupakan sumber air utama bagi tanaman khususnya tanaman tahunan. Rao dan Vijayakumar (1992) menyebutkan bahwa kebutuhan air tanaman karet selama satu bulan dapat tercukupi dengan curah hujan sebesar 100-150 mm. Kondisi ketidakcukupan air atau kekeringan akan menyebabkan pertumbuhan tanaman mengalami keterlambatan (Thomas, Sudiharto, Suryaningtyas, Nancy, \& Istianto, 2005). Pada Tabel 3 juga membuktikan bahwa pupuk majemuk tablet memiliki kemampuan untuk mengurangi pencucian hara (leaching) yang lebih baik dibandingkan briket. Hal ini dibuktikan dengan pertumbuhan lilit batang pada perlakuan pupuk tablet 300 $\mathrm{g} /$ pohon/tahun yang cenderung lebih tinggi dibandingkan briket pada bulan-bulan dimana air tersedia (Juli-Desember).

Pemupukan adalah satu upaya untuk meningkatkan pertumbuhan tanaman sehingga 
tanaman dapat segera memenuhi kriteria matang sadap pohon (lilit batang $\geq 45 \mathrm{~cm}$ ). Perlakuan pemupukan briket maupun tablet dalam penelitian ini mampu memacu pertumbuhan tanaman namun tidak dapat meningkatkan keseragaman tanaman. Hal tersebut terlihat dari nilai coefficient variation (CV) pada awal dan akhir penelitian yang berada pada kisaran 13,87-15,71\% (Tabel 4). Keseragaman tanaman pada masa belum menghasilkan (TBM) sangat menentukan produktivitas awal tanaman karet per satuan luas. Ketersediaan dan keseragaman umur bahan tanam (bibit) adalah faktor utama penentu keseragaman tanaman. Pengaruh pemupukan menjadi tidak maksimal pada tanaman yang memiliki ukuran diameter lilit batang yang kecil. Pada Tabel 4 dapat dilihat bahwa pada tiga perlakuan pemupukan penambahan ukuran lilit batang tanaman yang memiliki lilit batang terkecil (minimum) berkisar 1,5-4,2 cm/tahun. Sebaliknya tanaman yang memiliki lilit batang terbesar (maksimum) penambahan ukuran lilit batangnya jauh lebih tinggi yaitu 9,4-11,5 $\mathrm{cm} /$ tahun. Perbedaan ukuran lilit batang minimum dan maksimum yang cukup besar menyebabkan heterogenitas tanaman menjadi meningkat di akhir penelitian. Salah satu upaya untuk meningkatkan keseragaman lilit batang adalah dengan memberikan pupuk ekstra pada tanaman yang potensial untuk mengejar pertumbuhan tanaman yang normal. Pemupukan ekstra harus disertai dengan pengurangan tajuk/perompesan untuk mengurangi kompetisi dalam memperoleh cahaya matahari (Istianto \& Munthe, 2006).

\section{SIMPULAN DAN SARAN}

Pemupukan dengan pupuk majemuk tablet dan briket memberikan dampak yang positif bagi pertumbuhan lilit batang tanaman karet belum menghasilkan. Penggunaan pupuk majemuk tablet relatif lebih efisien karena dosis yang digunakan (g/pohon/tahun) lebih rendah serta jumlah aplikasi yang lebih sedikit (2x per tahun) dibandingkan dengan briket (kontrol). Pupuk majemuk tablet juga memiliki kemampuan yang lebih baik dalam mengurangi kehilangan hara akibat pencucian yang disebabkan karena pupuk tablet lebih lambat larut dibandingkan briket. Tingkat kelarutannya yang rendah menyebabkan kandungan hara daun nitrogen dan kalium pada tanaman yang dipupuk dengan pupuk tablet lebih rendah dibandingkan dengan kontrolnya.

Penelitian lanjutan terkait aspek sosial dan ekonomi (penggunaan tenaga kerja dan biaya pemupukan) sangat diperlukan agar mendapatkan hasil yang lebih komprehensif.

\section{UCAPAN TERIMA KASIH}

Perhargaan yang setinggi-tingginya kami haturkan kepada tim pengujian pupuk majemuk tablet, Ir. Istianto, M.S. dan Yushar. Ucapan terima kasih juga kami sampaikan kepada Manajemen KSPTH (PTP. Nusantara III) atas izin dan dukungan tenaga sehingga penelitian ini dapat berjalan dengan baik.

\section{REFERENSI}

Adiningsih, J., \& Mulyadi. (1993). Alternatif teknik rehabilitasi dan pemanfaatan lahan alang-alang. In S. Sukmana, Suwardjo, J. Sri Adiningsih, H. Subagjo, H. Suhardjo, \& Y. Prawirasumantri (Eds.), Pemanfaatan lahan alang-alang untuk usaha tani berkelanjutan (pp. 2950). Bogor, Indonesia: Pusat Penelitian Tanah dan Agroklimat, Badan Litbang Pertanian.

Agustin, L., Abdoellah, S., \& Bowo, C. (2010). Pemanfaatan kompos sabut kelapa dan zeolite sebagai campuran tanah untuk media pertumbuhan bibit kakao pada beberapa tingkat ketersediaan air. Pelita Perkebunan, 26(1), 12-24.

Arizal, R. (2001). Penggunaan karet alam sebagai matriks pupuk lepas lambat (Laporan akhir penelitian proyek penelitian dan pengembangan tanaman perkebunan). Bogor

Balai Penelitian Sungei Putih. (2004). Petunjuk praktis pengambilan sampel daun tanaman karet untuk rekomendasi pemupukan. Medan: Balai Penelitian Sungei Putih, Pusat Penelitian Karet.

Food and Agriculture Organization. (1980). Soil and plant testing as basis of fertilizer recomendation. Rome: FAO Soils Bulletin.

Hua, Y., Lin, Z., Luo, W., Cha, Z., \& Chen, Q. (2015). Evolution of soil fertility and its correlation with rubber tree leaf nutrient in rubber plantation. In Anonim (Ed.), 
Productivity and quality towards a sustainable and profitable natural rubber sector. International Rubber Conference 2015 (pp. 124-130). Ho Chi Minh City, Vietnam.

Idris, K. (1995). Pemberian posfat alam dari Jawa dan pengapuran pada tanah masam: Evaluasi agronomik. Jurnal Ilmu Pertanian Indonesia, 5(2), 63-68.

Istianto. (2006). Daur hara di perkebunan karet dan pemupukan tanaman karet menggunakan PUKALET. Warta Perkaretan, 25(1), 50-61.

Istianto., \& Munthe, H. (2006). Upaya meningkatkan keseragaman tanaman karet belum menghasilkan dengan pemupukan ekstra. In Sumarmadji, N. Siagian, S. Aidi_Daslin, Istianto, T. Kustyanti, \& I. Suhendry (Ed.), Budidaya Tanaman Karet 2006. Prosiding Lokakarya Nasional (pp. 220230). Medan, Indonesia.

Lan, R., Liu, Y., Wang, G., Wang, T., Kan, C., \& Jin, Y. (2011). Experimental modeling of polymer latex spray coating for producing controlled-release urea. Particuology, 9(5), 510-516. doi: 10.1016/j.partic.2011.01.004.

Nasution, M. Z. (1994). Penggunaan pupuk tablet pada tanaman karet. Medan: Pusat Penelitian Karet Sungai Putih.

Nasution, M. Z. (2002). Pengkajian dan penerapan berbagai pupuk posfat alam yang diasamkan terhadap pertumbuhan tanaman karet muda. Medan.

Nugroho, P. A., \& Istianto. (2010). Pemupukan tanaman karet di Indonesia: Sejarah singkat dan perkembangan. Warta Perkaretan, 29(1), 18-28.

Nugroho, P. A., \& Wijaya, T. (2017, October 18-20). Leaf nutrient status of rubber tree in different ecology zone of North Sumatra. Paper presented at thr International Rubber Conference 2017, Jakarta, Indonesia. Retrieved from http://ejournal.puslitkaret.co.id/index.php /proc/article/view/501/341

Prasetyo, B. H., \& Suriadikarta, D. A. (2006). Karakteristik, potensi, dan teknologi pengelolaan tanah ultisol untuk pengembangan pertanian lahan kering di Indonesia. Jurnal Litbang Pertanian,
25(2), 39-47.

Premono, E. (2006, September 4-6). Penggunaan pupuk PUKALET untuk mendukung peningkatan efisiensi dan produktivitas tanaman karet. In Sumarmadji, N. Siagian, A. Daslin, Istianto, I. Suhendry, \& and T. Kustyanti (Eds.), Budidaya Tanaman Karet 2006. Prosiding Lokakarya Nasional. Medan, Indonesia.

Rao, P. S., \& Vijayakumar, K. R. (1992). Climatic requirements. In M. R. Sethuraj \& M. Mathew (Eds.), Natural Rubber: Biology, Cultivation, and Technology. Amsterdam: Elsevier.

Shaviv, A. (2000). Advances in controlled release of fertilizers. Advances in Agronomy, 71, 1-49.

Supriyadi., Diana, N. E., \& Djumali. (2017). Pengaruh pupuk majemuk berbentuk granul dan briket terhadap pertumbuhan, produktivitas dan rendemen tebu. Buletin Tanaman Tembakau, Serat \& Minyak Industri, 9(1), 34-41.

Saputra, J., Ardika, R., \& Wijaya, T. (2017). Respon pertumbuhan tanaman karet (Hevea brasiliensis) belum menghasilkan terhadap pemberian pupuk majemuk tablet. Jurnal Penelitian Karet, 35(1), 49-58.

Syahputra, E., Fauzi, \& Razali. (2015). Karakteristik sifat kimia sub grup tanah ultisol di beberapa wilayah Sumatera Utara. Agroekoteknologi, 4(1), 17961803.

Tan, K. H. (1991). Dasar-dasar kimia tanah. (D. H. Geonardi, Terjemahan). Yogyakarta: Gadjamada University Press.

Thomas., Sudiharto., Suryaningtyas, H., Nancy, C., \& Istianto. (2005). Kultur teknis untuk mengurangi dampak kemarau panjang pada perkebunan karet. In Anonim (Ed.), Kumpulan makalah seminar sehari dampak dan antisipasi kemarau 2005 pada usaha agribisnis perkebunan. Bandung, Indonesia: Lembaga Riset Perkebunan Indonesia.

Trenkel, M. E. (2010). Slow and controlledrelease and stabilized fertilizers: An option for enhancing nutrient efficiency in agriculture (second). Paris, France: IFA. 